\title{
Zoom-Storytelling : an Activity to Reduce Students' Speaking Anxiety
}

\author{
Rini, Safrina. S. Noorman, \& Nia Nafisah \\ Universitas Pendidikan Indonesia, Bandung, Jawa Barat, Indonesia \\ rini2018@upi.edu, safrina@upi.edu, $\underline{\text { n_nnafisah@upi.edu }}$
}

Naskah diterima tanggal 07/05/2021, direvisi akhir tanggal 06/07/2021, disetujui tanggal 01/08/2021

\begin{abstract}
Abstrak
Dari empat keterampilan bahasa Inggris, keterampilan berbicara merupakan keterampilan yang paling sulit bagi siswa. Banyak alasan yang membuat siswa enggan berbicara bahasa Inggris, antara lain takut ditertawakan oleh temannya dan kurangnya rasa percaya diri. Faktor-faktor tersebut membuat siswa merasa cemas untuk berbicara dalam bahasa Inggris. Sejak diterapkannya pembelajaran dari rumah oleh pemerintah pusat akibat merebaknya Covid-19, siswa semakin tidak pernah berlatih berbicara dalam bahasa Inggris. Hal tersebut memperburuk tingkat kecemasan siswa untuk berbicara bahasa Inggris. Oleh karena itu, penelitian studi kasus kualitatif ini dilakukan untuk membantu mengurangi kecemasan siswa dalam berbicara bahasa Inggris dengan menggunakan zoom-storytelling, terutama ketika mereka diharuskan belajar dari rumah. FLCAS digunakan untuk mengukur tingkat kecemasan siswa. Hasil penelitian menunjukkan bahwa zoom-storytelling dapat mengurangi tingkat kecemasan siswa dalam berbicara bahasa Inggris. Melalui kegiatan zoom-storytelling ini, siswa terbantu untuk mendapatkan pembelajaran tatap muka secara virtual meskipun tidak berada di sekolah.
\end{abstract}

Kata kunci: Aplikasi Zoom, Storytelling, Speaking Anxiety.

Abstract

Among the four English skills, speaking is the most difficult skill for students. Many reasons make students reluctant to speak English, including being afraid of being laughed at by their friends and lack of confidence. These factors make students anxious to speak English. Since the implementation of learning from home by the central government due to the outbreak of the Covid-19, students have increasingly never practiced speaking English. It worsens the level of students' anxiety to speak English. Therefore, this qualitative case study research was conducted to help to reduce students' anxiety in speaking English by using zoom-storytelling, especially when they were required to learn from home. FLCAS was used to measure the student's anxiety level. The results showed that zoom-storytelling can reduce students' level of anxiety in speaking English. Through this zoom-storytelling activity, students were helped to get learning face-to-face virtually even though they were not in school.

Keywords: Zoom Application, Storytelling, Speaking Anxiety.

How to cite (APA Style): Rini, R., Noorman, S., \& Nafisah, N. (2021). Zoom-storytelling: An activity to reduce students' speaking anxiety investigating. Jurnal Penelitian Pendidikan, 21(2), 2021, 112-121 doi: https://doi.org/10.17509/jpp.v21i2.36653

\section{INTRODUCTION}

In Indonesia, English is one of the foreign languages taught in schools. However, English is rarely used by students outside of school. Therefore, students' speaking skills can only be practiced in the classroom. As a result, students rarely speak English. Meanwhile, the success of students speaking English is measured by their ability to communicate well in English. As explained by Nunan (1999), a person's success in learning a language is measured by his ability to carry out a conversation from the target language.

For students, learning speaking English is very difficult. Even, of the four English skills, speaking skills are the most difficult for students to understand (Horwitz, Horwitz, \& Cope, 1986). Many factors cause it difficult for them to speak English. Juhana (2012) states that psychological factors such as anxiety, fear of making mistakes, and embarrassment cause students to fail to speak English. These factors greatly influence the desire of students to learn to speak English.

As mentioned above, one of the factors that greatly affects the ability of students to speak English is students' anxiety about the language. Rachman (1998) concludes that anxiety is a feeling of nervous tension. The problem of student anxiety in learning English has been the focus of research from 
education experts since the 1970s. One study that was very influential on this research on anxiety is the research conducted by Horwitz, Horwitz, and Cope (1986). Many other researchers use the FLACS (foreign language anxiety classroom scale) from Horwitz, Horwitz, and Cope (1986) as a measuring tool to determine student anxiety levels.

Students' anxiety has to be lowered in order to improve students' abilities. Therefore, such research has to be carried out. The research can help the teachers who find it difficult to get their students to speak English. The research also helps the students who are studying from home because it is caused by the outbreak of the Covid-19 in Indonesia. So that even if students do not go to school, they still study wherever they are. Thus, the students can still practice speaking English where ever they are.

To keep students and teachers connected and still able to talk face-to-face, a forum is needed. Technology is now very advanced, people can talk and meet virtually anywhere in the world wherever they are. Therefore, in this study, the researchers use an application that is being used by many people as a forum to carry out the learning process for students even though they are at home. These applications really help students to keep learning.

There are many applications that can be used to keep in touch with other people, such as videoconferencing. Now, many people use videoconferencing to conduct meetings, such as online meetings, online classes, and many other activities. There are many video conferencing that can be used such as Zoom Cloud Meets App, Cisco WebEx, Google Hangout Meets, Skype, etc. In this study, the researcher uses the Zoom application to connect students and teachers in the learning process.

Meanwhile, to reduce the students' speaking anxiety level, the researchers choose storytelling as a model of the teaching and learning process. Storytelling is a learning model that has long been used (Nunan, 1988). Storytelling is also very helpful for students through learning experiences that create strong value when people listen to each other's stories (Bruner, 1990; Gils, 2005, and Thorpe, 2011). Rahmawati (2014) proves that using storytelling is effective for teaching speaking. So, by combining the use of zoom and storytelling students have the opportunity to learn to speak in a different atmosphere so that their anxiety can be reduced.

Anxiety, which is a barrier factor in the successful speaking of students, is actually experienced by many people of all ages. According to Horwitz, Horwitz, and Cope (1986), anxiety is a subjective feeling experienced by a person in learning a language in the form of tension, fear, nervousness, and worry related to the awakening of the autonomic nervous system. So, anxiety is a natural reaction of a person when experiencing a tense situation (Connolly, et al., 2006). Woodrow (2006) categorizes anxiety as trait anxiety and state anxiety. Trait anxiety is a relatively stable personality trait wherein a person tends to feel anxious in a variety of situations. Meanwhile, state anxiety is a temporary condition experienced at certain times.

In order to reduce the anxiety of students speaking English, appropriate learning techniques and models are needed. In this study, the writer used storytelling, which is entrusted with being able to attract students' attention and create an interaction between them. As stated by Flora (2011) that storytelling involves two-way interaction between the storyteller and the listener that creates interaction and cooperation. In addition, storytelling creates a positive, collaborative, and supportive classroom atmosphere (Atta-Alla, 2012). More deeply, storytelling is also a bridge to build student motivation and confidence (Wright, 1995). And most importantly, storytelling can improve students' English proficiency.

Storytelling provides many benefits for students in improving their English skills. First, storytelling provides context-meaning learning (Atta-Alla, 2012). In addition, storytelling increases students' motivation and self-confidence in speaking English (Wright, 1995). Furthermore, storytelling 
encourages students to think creatively in expressing their ideas and their thoughts. Storytelling also triggers the students' speaking and writing stimuli (Wright, 1995). Another benefit that students get is that storytelling enriches the student's learning experience.

The benefits that students get from the application of the storytelling above are expected to have a good effect on students' speaking anxiety. Researchers believe that by increasing students' motivation and self-confidence, the students' speaking anxiety will also decrease. Various learning experiences also help students reduce their speaking anxiety. Therefore, the researchers apply storytelling with a series of activities that are expected to not only reduce students' speaking anxiety but also improve their speaking skills. These activities are based on the learning stages of Wright (1995).

Wright (1995) divides this storytelling activity into three parts, namely pre-storytelling, during storytelling, and after storytelling. Pre-storytelling activities are activities carried out to build students' understanding of the story. Before storytelling activities can be in the form of showing pictures related to the story, providing new vocabulary, or playing games. Activities during storytelling are at the core of what students do in this teaching program. This activity can be in the form of the teacher telling a story, then students are asked to retell the story, and students are asked questions in the form of understanding the story. At other times, it is students who tell a story to their friends. The third activity is the activity after storytelling. This activity aims to determine the extent to which students understand the story. Usually, this activity is filled with the teacher giving questions about the story.

There are several studies related to storytelling and students' speaking anxiety. One of them is research conducted by Ono (2014), who investigates the use of digital storytelling to reduce students' foreign language anxiety at several universities in Japan. The results of his research show that digital storytelling has reduced foreign language anxiety. The results also show that there is an increase in student motivation and reluctance to skip class.

The second research is research conducted by Zuhriyah (2017), she explores the use of storytelling in speaking class in order to get new students to speak English. Through classroom action research, it is found that students' speaking skills improve after the implementation of storytelling, namely an increase in comprehension, fluency, vocabulary, grammar, and pronunciation.

Next is a research conducted by Sharma (2018) which raises the problem of cooperative storytelling strategies to improve the speaking skills of students from grade 11 students in Nepal. The results show that through the implementation of storytelling strategies, students' speaking ability is found to improve.

All of the studies described above that are conducted by previous researchers are different. This study focuses on students' anxiety in speaking English. Researchers assume that if students can overcome their anxiety, their speaking skills will also improve. This study uses a zoom application to make students practice the storytelling without having to come to school.

Based on the issues above, this study is intended to overcome students' speaking anxiety by using zoom-storytelling. This research is expected to help students to be more motivated to speak English.

\section{RESEARCH METHOD}

This research is descriptive qualitative research. This research was conducted to get a real picture of the level of student anxiety and how to overcome it by using zoom-storytelling. This research is also a case study because it was carried out in a school in the midst of the Covid-19 pandemic (Yin, 2008). During the Covid-19 pandemic, all students were required to study from home for an unknown amount of time. Therefore, this research was necessary to provide solutions for students in the speaking class while studying from home. 
As can be seen in Table 1, the participants in this study were five female students at a public high school in Rokan Hilir district, Riau province who had the highest level of anxiety from their classmates. They were in eleventh grade. The reason was that the eleventh graders were at the middle level in high school and they also had more experience in learning English. The selection of participants is expected to help them overcome their anxiety about speaking English.

Table 1. Zoom-Storytelling Pre-Implementation Questionnaire Score

\begin{tabular}{cccc}
\hline No. & Participant & Score & Anxiety Classification \\
\hline 1. & S1 & 132 & Very High \\
2. & S2 & 132 & Very High \\
3. & S3 & 131 & Very High \\
4. & S4 & 140 & Very High \\
5. & S5 & 136 & Very High \\
\hline
\end{tabular}

The results of the questionnaire above show that the five students are at a very high level of anxiety. This confirms that these students had problems in their speaking skills with a very high average anxiety. With reference to the results above, the five students were made participants in this study.

The data used in this study were questionnaires and semi-structured interviews. Questionnaires were used to measure the participants' level of anxiety in speaking English. In this case, researchers used a questionnaire from Horwitz, Horwitz, and Cope (1986), namely the FLCAS (foreign language classroom anxiety scale). The questionnaire was distributed to students twice, namely before and after zoom-storytelling. The questionnaire before the application of zoom-storytelling was given to students to determine the level of student anxiety in learning to speak English. While the second questionnaire was given to determine the level of students' speaking anxiety after the implementation of zoomstorytelling.

There were 31 statements contained in the questionnaire. It was translated in Bahasa Indonesia. The purpose of using Bahasa Indonesia was to make it easier for students to understand the questions in the questionnaire. The statements were divided into two parts, namely positive statements, and negative statements. Positive statements included statements number 2, 5, 8, 11, 17, 21, and 27. Meanwhile positive statements included statements $1,3,4,6,7,9,10,12,13,14,15,16,18,19,20,22,23,24,25$, 26, 28, 29, 30, and 31. The scale used was the Likert scale, namely strongly agree, agree, doubt, disagree, and strongly disagree. agree. There was a difference in scoring for positive and negative statements. The differences were described in Table 2.

Table 2. Likert Scale Score List

\begin{tabular}{llllll}
\hline \multicolumn{5}{c}{ Score } & SD \\
\hline Pernyataan & SA & A & N & D & S \\
Positif & 1 & 2 & 3 & 4 & 1 \\
Negatif & 5 & 4 & 3 & 2 & 1 \\
\hline
\end{tabular}

Note: $\mathrm{SA}=$ Strongly Disagree; $\mathrm{A}=$ Agree; $\mathrm{N}=$ Neutral; $\mathrm{D}=$ Disagree; $\mathrm{SD}=$ Strongly Disagree.

To determine the level of student anxiety, the researchers use the classification from Kardaş and Koç (2017). The classification can be seen in Table 3. 
Table 3. Classification of Speech Anxiety Levels

\begin{tabular}{ll}
\hline Range Score of Questionnaires & Level of Speaking Anxiety \\
\hline $\mathbf{3 1}-\mathbf{5 5}$ & very low anxiety \\
$\mathbf{5 6}-\mathbf{8 0}$ & low anxiety \\
$\mathbf{8 1}-\mathbf{1 0 5}$ & intermediate anxiety \\
$\mathbf{1 0 6}-\mathbf{1 3 0}$ & high anxiety \\
$\mathbf{1 3 1}-\mathbf{1 5 5}$ & very high anxiety \\
\hline
\end{tabular}

The second data was a semi-structured interview. Semi-structured interviews were used to determine student responses to the application of zoom-storytelling. Interviews were conducted after the zoom-storytelling was carried out. Each participant was interviewed to find out their response about the use of zoom-storytelling to their speaking anxiety.

All the data were analyzed qualitatively. Data from the questionnaire is presented in the form of descriptive statistics. The results of the questionnaire data were used to determine the level of students' speaking anxiety after zoom-storytelling was implemented. Likewise, data from interviews are presented descriptively as well. In analyzing the interview data, the researchers used the steps, namely coded, categorized, synthesized based on the need of the research to answer the research questions.

\section{RESULT AND DISCUSSION Results}

This research was conducted to provide a solution to the students' speaking anxiety. To determine that zoom-storytelling is successful in reducing students' speaking anxiety, it is necessary to measure it using the FLCAS (Horwitz, Horwitz, and Cope, 1986). The results of the first questionnaire that were distributed before students got the zoom-storytelling showed that the five participants were at a very high level. So that, to reduce students' English speaking anxiety, they were given a zoom-storytelling learning model. The results of the questionnaire after applying zoom-storytelling are shown in Table 4.

Table 4. The Second Questionnaire Score

\begin{tabular}{cccc}
\hline No. & Participants & Score & Anxiety Classification \\
\hline 1. & S 1 & 83 & Intermediate \\
2. & S 2 & 79 & Low \\
3. & S 3 & 83 & Intermediate \\
4. & S 4 & 89 & Intermediate \\
5. & S5 & 90 & Intermediate \\
\hline
\end{tabular}

The results of this second questionnaire showed a decrease in students' speaking anxiety. This indicates that the overall zoom-storytelling applied to the participants has helped them reduce their fear of speaking English. It is evidenced by their average English speaking anxiety score is at a moderate level. It has a great influence on their learning to speak English. The complete results of the second questionnaire can be seen in Table 5.

Table 5. The Results of FLCAS Post Zoom-Storytelling

\begin{tabular}{|c|c|c|c|c|c|}
\hline Statements & $\mathbf{S A}$ & $\mathbf{A}$ & $\mathbf{N}$ & $\mathbf{D}$ & SD \\
\hline $\begin{array}{l}\text { 1. I never feel quite sure of myself when I am speaking during } \\
\text { Zoom Storytelling. }\end{array}$ & 0 & 0 & 1 & 3 & 1 \\
\hline 2. I don’t worry about making mistakes in Zoom Storytelling. & 0 & 4 & 0 & 1 & 0 \\
\hline $\begin{array}{l}\text { 3. I tremble when I know that I'm going to be called on in Zoom } \\
\text { Storytelling. }\end{array}$ & 0 & 3 & 0 & 2 & 0 \\
\hline
\end{tabular}




\begin{tabular}{ccccccc}
\hline Statements & SA & A & N & D & SD \\
\hline 4. It frightens me when I don't understand what the teacher is & 0 & 3 & 0 & 2 & 0
\end{tabular}
saying in English.

5. It wouldn't bother me at all to take more Zoom Storytelling. $\quad \begin{array}{llllll}0 & 5 & 0 & 0 & 0\end{array}$

6. During the Zoom Storytelling, I find myself thinking about $\begin{array}{llllll}0 & 0 & 3 & 2 & 0\end{array}$ things that have nothing to do with the activity.

7. I keep thinking that the other students are better at English than $\begin{array}{lllllll}0 & 4 & 0 & 1 & 0\end{array}$ I am.

8. I am at ease during speaking test after the Zoom Storytelling $\begin{array}{lllllll}0 & 5 & 0 & 0 & 0\end{array}$ activity.

9. I begin to panic when I have to act without preparation in the $\begin{array}{lllllll}0 & 1 & 4 & 0 & 0\end{array}$ Zoom Storytelling.

10. I worry about the consequences of failing my performance in the Zoom Storytelling.

11. I don't understand why some people get so upset over Zoom Storytelling.

12. In Zoom Storytelling, I can get so nervous I forget things I know.

13. It embarrasses me to volunteer answers in my Zoom $0 \begin{array}{lllll}0 & 0 & 3 & 2\end{array}$ Storytelling.

14. I get upset when I don't understand what the teacher is $\begin{array}{lllllll}0 & 2 & 2 & 1 & 0\end{array}$ correcting.

15. Even if I am well prepared for Zoom Storytelling, I feel anxious $\begin{array}{lllllll}0 & 4 & 0 & 1 & 0\end{array}$ about it.

16. I often feel like not going to join with the Zoom Storytelling.

17. I feel confident when I speak in Zoom Storytelling.

18. I am afraid that my English teacher is ready to correct every mistake I make

19. I can feel my heart pounding when I'm going to be called on in Zoom Storytelling.

20. The more I study for Zoom storytelling, the more confused I get.

21. I don't feel pressure to prepare very well the Zoom Storytelling performance.

22. I always feel that the other students speak English better than me.

23. I feel very self-conscious about speaking English in front of other students.

24. Zoom Storytelling moves so quickly I worry about getting left behind.

25. I feel more tense and nervous in my Zoom Storytelling activity than in my other class activity.

26. I get nervous and confused when I am speaking in my Zoom Storytelling.

27. When I'm on my way to join Zoom Storytelling, I feel very sure and relaxed.

28. I get nervous when I don't understand every word the English teacher says.

29. I feel overwhelmed by the number of rules you have to learn to speak English.

30. I am afraid that the other students will laugh at me when I speak English.

31. I get nervous when the English teacher asks questions which I haven't prepared in advanced. 
Based on the results of the table above, it is found that students' speaking anxiety is caused by different sources of anxiety. According to Sağlamel and Kayaoğlu (2013), there are several sources of anxiety that can be found in the FLCAS above, including lack of confidence, fear of failure, physical and mental avoidance, lack of desire to participate in speaking classes, competitiveness, and perfectionism. The results of the questionnaire above are explained based on the source of anxiety according to Sağlamel and Kayaoğlu (2013).

The factor of lack of self-confidence is contained in statements 1, 13, 15, 17, 23, and 30. From the results shown in the table, it can be seen that students have started to develop self-confidence. They have started to believe and be confident to speak English (four students, as seen in no. 1 and 17. They also felt less embarrassed about answering questions from teachers voluntarily (statement 13). Three students stated that they are not afraid of being laughed at by their friends when they speak English, which indicates that they feel confident about themselves (statement 30). However, two students still feel embarrassed to speak English in front of their peers (statement 23). They still feel anxiety, even though they have prepared well. This can be seen in statement 15 where almost all participants still feel it. It is in line with Liu (2007) who finds that students' speaking anxiety could arise even though they have made careful preparation.

Fear of failure is found in statements $2,4,10,14,18,24,29$. The fear of failure often becomes a barrier for students to avoid doing something. However, after the implementation of zoom-storytelling in learning to speak English, students are no longer afraid of failure. It motivates them to try to show their best. This fact can be seen from almost all students stated that they are not afraid to make mistakes again in their speaking class (statement 2). They also do not worry about the consequences they receive for failing in their speaking performance (statement 10). Some students feel this situation. Students also give good responses to the fact that the teacher corrects their mistakes in speaking. It can be seen in questionnaire no. 18, all students give positive responses. However, due to the fact that they still feel overwhelmed by the rules of speaking English, almost all students still feel they cannot follow these rules (statement 29). Fear of not understanding what the teacher said also still gets a high percentage, namely 60\% (statement 4). It is in line with Punsiri's research (2011), one of the anxiety factors is that students feel anxious about not understanding what their teachers said.

Physical and mental avoidance is one of the sources of anxiety that often makes students avoid speaking English. Statements 3, 12, 19, 25, 26, and 27 are parts of anxiety in the form of physical and mental avoidance. After implementing zoom-storytelling, students do not avoid speaking class anymore. It is proven by four students who are not nervous and confused about speaking in the zoomstorytelling class (statement 26). In addition, three students already feel relaxed so they do not forget their words when speaking (statement 12). three students also feel unafraid when they are called to join a speaking class (statement 3). In some cases, four students still think the speaking class is tenser than other learning classes (statement 25). two students still tremble when their name is called (statement 19). It is supported by a study conducted by Liu (2007) that supports the phenomenon that students felt anxious about being called by the teacher in learning speaking. On the other hand, they have not been able to determine the attitude of whether they feel relaxed when they will take speaking classes. Three students still answer doubtfully.

Lack of interest in participating in speaking class is also a source of student anxiety, which was found in statements 5, 6, and 16. In connection with this, it was found that several things had changed after the students participated in the zoom-storytelling, including the students' responses which stated that they were happy if the zoom-storytelling was carried out more often (all students). This response is found in statement 5 . In statement 16 , it can be seen that three students do not want to miss the 
speaking class. However, it was also found that when learning activities used zoom-storytelling, only two students believed they could construct (statement 6).

The following findings relate to competitiveness (statements 7 and 22). These findings indicate students are still afraid to compete with classmates in speaking. It can be seen from four students who feel their friends speak English more, especially speaking English. The previous study shows some students feel that they are competing with their friends and they feel they are not good rather than their friends (Sağlamel \& Kayaoğlu, 2013). The study is in line with the findings of this study.

Findings related to perfectionism (statements 9, 21, 28, and 31), show some findings that show student responses are still doubtful (statements 3 and 31). However, an interesting fact is also found where all students respond that they do not feel pressured in preparing their performance in speaking class.

The second data in this research was the interview. The result showed that after implementing zoom-storytelling, their anxiety can be alleviated. As one of the participants says,

\#S2 : 'menurut saya zoom itu bagus karena dapat memudahkan guru dan siswa dalam berinteraksi jadi seperti sedang berada dikelas. Jadi mendongeng dengan zoom membuat saya lebih berani berbicara'. (I think zoom is good because it can make it easier for teachers and students to interact so that it is like being in class. So zoom storytelling made me more courageous to speak).

Based on the quote above, students feel more courageous in speaking English after using zoomstorytelling. According to them, learning by using zoom-storytelling gives them the opportunity to express their opinion through stories. It is supported by the argument of Buerba (2019) which states that storytelling can inspire and stimulate students' minds towards low anxiety.

The results also showed that the students' confidence increased after they implemented zoomstorytelling. During zoom-storytelling activities, students get many opportunities to speak English. It affects their self-confidence increase. As one participant said:

\#S4 :'Menurut saya bagus ... karena bisa meningkatkan percaya diri saya dan memudahkan siswa untuk bertanya langsung dan berinteraksi seperti sedang didalam kelas. Selama corona ini biasanya siswa berinteraksi dengan guru melalui chattingan, jadi kalau ada kegiatan seperti ini bisa membantu saya berbicara Bahasa Inggris. Gak diam aja'. ('I think it's good ... because it can improve and make it easier for students to ask questions directly and interact as if they were in class. During this coronavirus, students usually interact with teachers through chatting, so if there is an activity like this it can help me to speak English. No only keep silent).

\section{Discussion}

The findings obtained from the results of the questionnaire and interview show that using zoomstorytelling can reduce students' anxiety in speaking English. The results of the questionnaire showed a decrease in the level of student anxiety. The interview results showed that the students felt that zoomstorytelling helped relieve their anxiety and increase their self-confidence. It means that zoomstorytelling helps students overcome their problems in English speaking anxiety. These findings are also found in previous research conducted by Ono (2014). Through mixed methods, this study investigates the use of digital storytelling to reduce students' speaking anxiety and PBL skills in firstyear students: Integrated English. Here, research reports that the PBL approach to digital storytelling has an impact on reducing anxiety and increasing student motivation.

The findings in this study were obtained from a questionnaire to answer students' anxiety based on the source of their anxiety. There are several sources of student anxiety, namely lack of confidence, fear of failure, physical and mental avoidance, lack of desire to attend speaking classes, competitiveness, and perfection (Sağlamel \& Kayaoğlu, 2013). Overall, the sources of students' speaking anxiety that prevent them from speaking more actively are able to be reduced by applying 
zoom-storytelling. The activities they do zoom-storytelling help them stay active while they are learning from home.

Speaking anxiety can be reduced by activities carried out by students in zoom-storytelling. Activities that are made in a structured manner can help students reduce anxiety in speaking English. This condition is in line with the argument from Samantaray (2014) which states that storytelling can gather and build students' confidence in speaking.

Zoom-storytelling is designed and performed in structured and varied activities. All of this is done with the aim of making it easier for students to participate in activities. The activities are designed from the easiest to the most difficult. These activities are also organized in order to help students active in speaking English. As suggested by Lavefer (2009) which suggests students need a lot of oral interaction so that they can speak English. By doing this, it raises their interest in speaking English class. These activities also provide an interesting and enjoyable learning experience. Thus, student anxiety can be reduced.

Another impact felt by students is that storytelling increase students' confidence to speak English. Storytelling activities force them to talk a lot. The more often they speak, the more they increase their vocabulary. With more vocabulary, they are more confident to speak. Thus, the anxiety they often felt before implementing storytelling through videoconferencing is reduced. It is in line with research conducted by Buerba's (2019) study which reveals that storytelling activities support students in managing speaking anxiety. If students are able to manage their anxiety, then their self-confidence will arise.

\section{CONCLUSIONS}

The purpose of this study was to reduce students' English speaking anxiety by applying zoomstorytelling. Based on the results of the FLCAS, the results showed that the students' speaking anxiety had decreased. Although not all aspects have decreased, the students can still overcome this anxiety. Thus, it is believed that zoom-storytelling reduces students' speaking anxiety.

Based on students' perceptions, storytelling reduces their speaking anxiety, it also fosters a pleasant learning atmosphere. By zoom-storytelling, students discover new learning experiences and increase their confidence to speak English.

By using zoom-storytelling, it is hoped that this activity can become a learning activity or as an extracurricular activity that can reduce students' anxiety in speaking English and also improve their speaking skills. It is also hoped that the zoom-storytelling can be applied to different levels of education and other English language skills.

\section{REFERENCES}

Abbasi, M., \& Behjal, F. (2018). The effect of storytelling via telegram on Iranian EFL learners' speaking complexity. International Journal of Educational Investigation, 5(2), 28-40.

Atta-Alla, M. (2012). Integrating language skills through storytelling. English Language Teaching, $5(12)$.

Bruner, J. (1990). Culture, mind, and education. In K. Illeris (ed.), Contemporary theories of learning: Learning theorists .... in their own words. London and New York: Routledge.

Connolly, S., \& et.al. (2006). Anxiety disorder. New York: Chelsea House Publisher.

Gils, F. V. (2005). Potential applications in digital storytelling in education. 3rd Twente Student Conference on IT.

Horwitz, E. K., Horwitz, M., \& Cope, J. (1986). Foreign language classroom anxiety. The Modern Language Journal, 70(2), 125-132. 
Juhana. (2012). Psychological factors that hinder students from speaking in English class (A case study in a senior high school in South Tangerang, Banten, Indonesia). Journal of Education and Practice, 3(12), 100-110.

Lavefer, S. (2009). Are national curriculum objectives for teaching English being met in Iceland compulsory school? Timarit um menntarannsoknir, 6, 107-128.

Liu, M. (2007). Anxiety in oral English classroom: A case study in China. International Journal of English Language Teaching, 3(1).

Nunan, D. (1999). Second language teaching and learning. Boston: Heinle Publishers.

Nunan, D. (1988). Syllabus design. Oxford: Oxford University Press.

Ono, Y. (2014). Effects of digital storytelling and Japanese EFL learners. Focus on anxiety and PBL skills. New Perspectives on the development of communicative and related competence in foreign language education (pp. 339-362). De Gruyter.

Punsiri, B. (2011). The effectiveness of drama techniques on foreign language classroom anxiety reduction of Thai EFL students (A Master's thesis). Srinakharinwirot Univeristy, Thailand.

Rachman, S. (1998). Anxiety. East Sussex: Psychology Press.

Rahmawati, I. (2014). Teaching speaking through storytelling (An unpublished Master's Thesis) Universitas Pendidikan Indonesia, Indonesia.

Saglamel, H., \& Kayaoglu, M. N. (2013). Creative drama: A possible way to alleviate foreign language anxiety. RELC Journal, 44(3), 377-394.

Samantaray, I. (2014). Use of storytelling method to develop spoken English skills. International Journal of Language \& Linguistics, 1(1), 40-44.

Sharma, D. (2018). Action research on improving students' speaking proficiency in using cooperative storytelling strategy. Journal NELTA Surkhet, 5, 97-105.

Thorpe, S. (2011). Using storytelling in the facilitation of online groups. International Association of Facilitators, 11, 24-39.

Woodrow, L. (2006). Anxiety and Speaking English as a Second Language. RELC Journal, 37(3), 308328

Wright, A. (1995). Storytelling with children: Resource books for children. Oxford: Oxford University Press.

Yin, R. (2009). Case study research: Design and methods. Los Angeles: Sage.

Zuhriyah, M. (2017). Storytelling to improve students' speaking skill. Journal Tadris Bahasa Inggris, 10(1), 119-134. 